\title{
PROCESS MODELING AND SCENARIO SIMULATION IN CONSTRUCTION USING ENTERPRISE DYNAMICS SIMULATION SOFTWARE
}

\author{
Mario Galić \\ Josip Juraj Strossmayer University of Osijek, Faculty of Civil Engineering Osijek, mag.ing.aedif. \\ Corresponding author: mgalic@gfos.hr \\ Ralf Thronicke \\ Bauhaus-Universität Weimar, B.Sc. \\ Benjamin Michael Schreck \\ Bauhaus-Universität Weimar, B.Sc. \\ Immo Feine \\ Bauhaus-Universität Weimar, Dipl.-Ing. \\ Hans-Joachim Bargstädt \\ Bauhaus-Universität Weimar, Professor Dr.-Ing.
}

\begin{abstract}
Modeling and simulation of organizational processes are established methodologies and tools in most industries. In civil engineering, however, this is not the case. One of the reasons for this is the lack of special tools, specifically computer programs used primarily for modeling and simulating characteristic processes of construction. In this paper the authors look for analogies between processes typical for construction and those in other industries in which Enterprise Dynamics software has been successfully applied. In order to perform a valid software analysis, the authors tested this software in a case study that represents universal problems at construction sites: queuing and sequencing. In this study, authors modeled and simulated the production, transport, and laying of a hot asphalt mixture. Results show that this software is suitable for modeling and scenario simulation in this case and that the software shows promise for other uses in the construction industry.
\end{abstract}

Keywords: process, modeling, scenario, simulation, transportation, asphalt, Enterprise Dynamics software

\section{MODELIRANJE I SIMULACIJA SCENARIJA GRAĐEVINSKIH PROCESA POMOĆU RAČUNALNOG PROGRAMA ENTERPRISE DYNAMICS}

Sažetak: Modeliranje i simulacija organizacijskih procesa u gotovo svim gospodarskim granama ima već potvrđenu metodologiju i alate za uporabu. U građevinarstvu, međutim, još nije zaživjela u toj mjeri, a jedan od razloga je nepostojanje specijalnog alata - računalnog programa primarne namjene modeliranja i simulacije procesa karakterističnih za građevinarstvo. U ovome radu autori su, analogijom pronalaska sličnosti procesa između pojedinih industrija i građevinarstva, napravili analizu računalnog programa Enterprise Dynamics koji je uspješno primijenjen u spomenutim industrijama. Kako bi se izvršila opravdana analiza programa, autori su ga testirali na primjeru koji predstavlja univerzalni problem na gradilištima - redovi čekanja i redoslijed (primjer modeliranja i simulacije proizvodnje, transporta i ugradnje vrućeg asfalta). Rezultati su pokazali da je program pogodan za modeliranje i simulaciju scenarija za spomenutu vrstu problema, no i da ima potencijala za uspješno rješavanje, modeliranjem i simulacijom, i drugih problema u građevinarstvu.

Ključne riječi: proces, modeliranje, scenarij, simulacija, transport, asfalt, Enterprise Dynamics računalni program 


\section{INTRODUCTION}

When a project's problems and goals exceed the limit of human imagination, then modeling and simulation come to mind. Although, complexity is not the only reason for using these methods, sometimes the lack of execution time is the most important argument to use modelling and simulation for problem simplification [1]. Until recently, simulation has only been used in civil engineering for simplifying objects in construction systems, while organizational processes have been neglected. However, other industries - such as healthcare and automotive production, as well as services like airlines and banks - have applied modeling and scenario simulations for quite some time to improve their performance. Seeing this improvement, software companies have become more interested in these methods, and now there are numerous computer programs available for process modeling and simulation. As competition increases between construction companies because of further globalization, this software is a powerful option to increase effectiveness [2-5], cut costs, and save time.

Virtual models and simulations are important tools in production and logistics. By modeling and simulating processes, a company can much more easily describe and analyze production without constructing prototypes; they can also run experiments and test new products or even entire production lines while using little time and money. This approach adds value with scenario simulation: changing input parameters generates multiple scenarios, which can be used to enable and improve decision-making, design orientation, and quantitative assessments. Especially in mass production, process simulations are good tools for optimizing processes and increasing efficiency because the various work steps in the production line are repeated constantly as long as the basic conditions remain stable.

In contrast, the construction industry produces unique items and has no fixed production lines. Although the individual work steps are repeated at every construction site, the virtual model must be shaped according to the conditions of each new construction project. For this reason, use of process simulations is limited to large and complex projects, where the effort might generate sufficient savings.

\section{METHODOLOGY}

This paper consists of three parts. In the first part, we give a literature review to assess the field of process modeling and simulation, focusing on the construction industry and on the achievements of previous researches which applied Enterprise Dynamics (ED) software.

In the second part, we describe a case study project: a process chain of production, transportation, and paving of a hot asphalt mixture (HMA). We modeled this process in ED. The model was structured of three sub-processes: production (source), transportation, and laying (sink) that fulfilled the general requirements of a separate interface for input parameters via Microsoft Excel as well as an interface for storing the simulation output.

In the third part, we analyzed the potential for and constraints of further applying ED in the construction industry.

\section{LITERATURE REVIEW}

\subsection{Process modeling and scenario simulation}

Simulation is modeling of an abstracted, dynamic system in order to solve special problems, to find answers to certain questions, or in general to gain knowledge which can later be applied. A model is defined as a simplified representation of a particular section of reality [6]. According to Wainer and Mosterman [7], the main objective of a simulation is to determine how changing an input affects a system or local parts of it. Process modeling and simulation lets the user compare procedures and their constraints, improving their understanding of the procedure and scenarios, allowing them to make decisions based on quantitative data.

\subsection{Modeling and simulation of construction processes}

Various authors previously have pointed out different software for simulating construction processes (e.g. CYCLONE, STROBOSCOPE, Simphony) because their use is supposedly well established in the industry. However, Wainer and Mosterman stress two main issues related to the mentioned programs: 
- the tools' graphic power to illustrate the model is limited and

- the results are only available as numeric or statistical data [7].

These arguments limit the use of those tools to specialised engineers, and it constraints the communication in any project. Thus, in this research we have analyzed ED software to see whether it could provide: graphical and numerical representations of both the results and the model, and to assess whether it is compatible with a separate input file, by which the input parameters could be monitored and the model could be controlled. Up to now, modeling and simulation have been used to resolve spatial conflicts on construction sites [8-10], to model asphalt paving during lane closure [11], and to optimize stockyard layouts for precast concrete products by comparing various layout scenarios [12]. In these applications, Wainer et al. stated that "...available construction simulation tools can provide the logical relationships between the different resources; however, they are not suited to define the spatial relationships between resources on a specific construction site." [7, p. 310]. With this issue in mind-that of the spatial relationships between resources-we believe it can be solved by using data-oriented software (such as Microsoft Excel or Access) that is compatible with ED, which can import input parameters, and can export results.

\subsection{Enterprise Dynamics software and 4D script programming language}

Enterprise Dynamics has versatile uses in various fields. It is an object-oriented program useful for modeling, simulation, visualization, and control of dynamic processes [13]. Up to now, this software has been used to model and simulate very different problems in various industries. These are some examples:

(a) Modeling and simulating the transhipment of a freight depot. This work showed that the simulation software is useful for coordinating terminals when the inflow and outflow of goods is already known [14].

(b) Modeling and simulating the spatial layout of a stockyard. The primary task was to control the vehicles in the yard, the loading and unloading of the cargo, and the transport, sorting, and buffering operations within the hall [15].

(c) Optimizing the configuration of production control. The task was to compare configurations in order to identify the most important parameters [16].

While ED has been used in various industries, the only published report of its use in civil engineering is the doctoral thesis by Weber in 2007, who analyses logistic processes on construction sites [17]. The aim of this simulation was to optimize resource use, avoid waiting times at intersections, and estimate the construction duration. After extending ED with special functions for the construction industry, Weber demonstrated its functionalities in a specific example, a construction project with three structures: an underground parking area, a three-story semi-circular attachment, and a twelve-story main building. Testing various strategies, the simulation showed that the logistical processes should be flexible and not time-critical, the deliveries should be distributed over longer time periods, and that several small warehouses on the site should be used instead of one central location. This analysis shows that ED is promising for simulating construction logistics processes; as such, the catalog of atoms, as the objects are called in ED, should be expanded and refined [17]. Table 1 gives a general comparison of ED with similar simulation software (eM-Plant, SimPro, and AutoMod) [18].

As shown in Table 1, ED is built in the 4DScript programming language. In this language, one can create or set specific conditions and create specific atoms. We used this functionality, as we will later describe in more detail, in the case study. It is not necessary to have specific knowledge of $4 \mathrm{DS}$ Script. It is precise and comfortable for inexperienced users, and it offers an extensive list of predefined orders. 
Process modelling and scenario simulation in construction using Enterprise Dynamics Simulation software

Table 1 - Comparison of ED and similar simulation software [16]

\begin{tabular}{|c|c|c|c|c|}
\hline Criteria & \multicolumn{4}{|c|}{ Simulation software } \\
\hline Interfaces & eM-Plant & Enterprise Dynamics & SimPro & AutoMod \\
\hline Import of parameters & $\begin{array}{l}\text { ODBC-/Oracle-/ASCII-block, } \\
\text { SimTalk }\end{array}$ & $\begin{array}{l}\text { ODBC, ASCII } \\
\text { Excel } \\
\text { 4D Script }\end{array}$ & $\begin{array}{l}\text { ADO-, OLE-DB, ASCII Modula- } \\
2\end{array}$ & $\begin{array}{l}\text { ASCII, } \\
\text { AutoMod-SL }\end{array}$ \\
\hline $\begin{array}{l}\text { Generation of model by } \\
\text { external modeling }\end{array}$ & SimTalk & 4D Script & $\mathrm{N} / \mathrm{A}$ & not possible \\
\hline External simulation control & SimTalk, COM & 4D Script & Modula-2 & AutoMod-SL \\
\hline Export of results & $\begin{array}{l}\text { ODBC, Oracle, ASCII, } \\
\text { HTML, SimTalk }\end{array}$ & $\begin{array}{l}\text { ODBC, ASCII, } \\
\text { Excel, (HTML), } \\
\text { 4DScript }\end{array}$ & $\begin{array}{l}\text { ADO-, OLE-DB, ASCII Modula- } \\
2\end{array}$ & $\begin{array}{l}\text { ASCII, } \\
\text { AutoMod-SL }\end{array}$ \\
\hline Connection technologies & $\begin{array}{l}\text { to SimTalk: } \\
\text { FileIO, DDE (contained), } \\
\text { ActiveX, C, Socket, COM, } \\
\text { HTML }\end{array}$ & $\begin{array}{l}\text { to 4D Script: } \\
\text { FilelO, ActiveX, Socket, DDE, } \\
\text { COM, (HTML) }\end{array}$ & $\begin{array}{l}\text { to Modula-2: } \\
\text { FilelO, COM, Java- Wrapper, } \\
\text { ADO-, OLE-DB }\end{array}$ & $\begin{array}{l}\text { to AutoMod-SL: } \\
\text { FilelO, ActiveX }\end{array}$ \\
\hline Programming language & $\begin{array}{l}\text { SimTalk, C-Block, } \\
\text { via connection: } \\
\mathrm{C}, \mathrm{C}++, \mathrm{VB}, \ldots \\
\end{array}$ & $\begin{array}{l}\text { 4D Script, } \\
\text { via connection: } \\
\mathrm{C}, \mathrm{C}++, \mathrm{VB}, \ldots \\
\end{array}$ & $\begin{array}{l}\text { Modula-2, Java, } \\
\text { via connection: } \\
\text { C, C++, VB,... }\end{array}$ & $\begin{array}{l}\text { AutoMod-SL } \\
\text { via connection: } \\
\mathrm{C}, \mathrm{C}++, \mathrm{VB}, \ldots .\end{array}$ \\
\hline Access scheduler & limited & yes & yes & no \\
\hline \multicolumn{5}{|l|}{ Modeling } \\
\hline $\begin{array}{l}\text { Modeling concept (object- } \\
\text { oriented, hierarchical) }\end{array}$ & object-oriented, hierarchical & object-oriented, hierarchical & hierarchical & limited hierarchical \\
\hline Definition of specific blocks & possible & possible & possible & not possible \\
\hline $\begin{array}{l}\text { Reuse of the reference } \\
\text { system }\end{array}$ & possible & possible & possible & possible \\
\hline $\begin{array}{l}\text { Continued use for refined } \\
\text { simulation }\end{array}$ & very good & very good & $N / A$ & limited \\
\hline Scale & $\begin{array}{l}\text { 2D: not given } \\
\text { 3D: given } \\
\end{array}$ & $\begin{array}{l}\text { 2D: given } \\
\text { 3D: given }\end{array}$ & $\begin{array}{l}\text { 2D: given } \\
\text { 3D: not given }\end{array}$ & $\begin{array}{l}\text { 2D: given } \\
\text { 3D: given }\end{array}$ \\
\hline Runtime behavior & medium & good & $\mathrm{N} / \mathrm{A}$ & medium \\
\hline Development cooperation & bad & good & very good & bad \\
\hline
\end{tabular}

\section{PROCESS MODELING AND SIMULATION WITH ED}

\subsection{Structuring the model}

Figure 1 shows an illustration of how we structured and connected the Excel file holding the input parameters to the ED model, exported the results to the same file (but at a different location) of input parameters, and then run the experiment (simulation). The feedback connection represents the iterative nature of modeling and simulation. This nature means that the model should be structured to allow for simulations of various scenarios after the initial simulation, keeping the results of each simulation for post-simulation analysis.

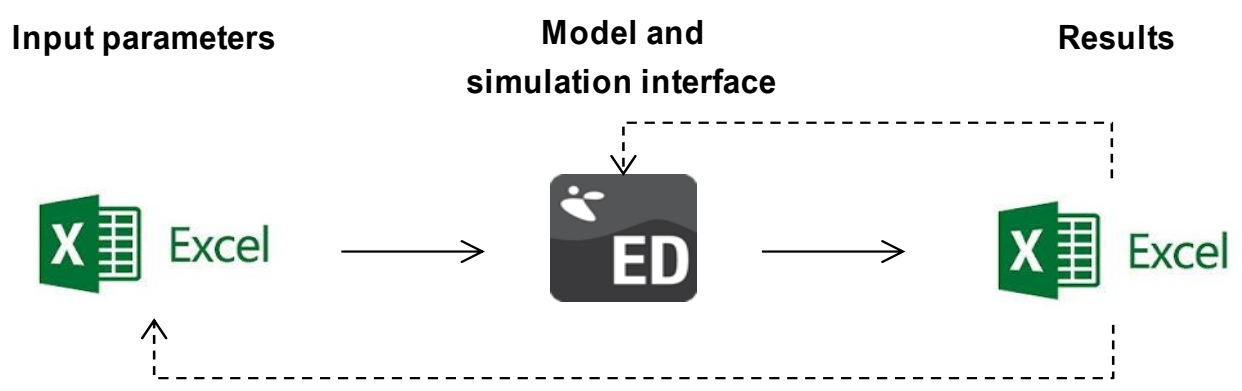

Figure 1 Illustration of the connection between the model interface and input/output file 
Process modelling and scenario simulation in construction using Enterprise Dynamics Simulation software

To give the details underlying Figure 1, Figure 2 shows the input parameters, explains how the model is structured ( $\boldsymbol{n}$ is the total number of sources, $\boldsymbol{N}$ is the total number of transportation vehicles, $\boldsymbol{m}$ is the total number of construction sites), and shows the methodology for exporting the results.

\begin{tabular}{|c|c|c|c|c|c|c|c|}
\hline \multicolumn{3}{|c|}{ Input parameters } & \multicolumn{3}{|c|}{ Model } & \multicolumn{2}{|c|}{ Results } \\
\hline Production & Transport & Sites & Production & Transport & Sites & & \\
\hline $\begin{array}{l}\text { number of } \\
\text { asphalt plants }\end{array}$ & $\begin{array}{l}\text { type and } \\
\text { number of } \\
\text { trucks }\end{array}$ & $\begin{array}{l}\text { number of } \\
\text { sites }\end{array}$ & 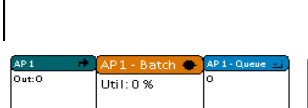 & Transporter 1 & \begin{tabular}{|l|l|}
$\operatorname{CS} 1-$ Laving & $\operatorname{css} 1$ \\
Util: $0 \%$ & In:0 \\
\end{tabular} & & Initialize \\
\hline $\begin{array}{l}\text { nominal } \\
\text { hourly } \\
\text { capacity } \\
\text { [thour] }\end{array}$ & $\begin{array}{l}\text { capacity of } \\
\text { trucks [tons] }\end{array}$ & $\begin{array}{l}\text { needed } \\
\text { quantity of } \\
\text { asphalt [tons] }\end{array}$ & & & & Excel Activex & Table \\
\hline $\begin{array}{l}\text { location of } \\
\text { asphalt plants }\end{array}$ & \begin{tabular}{|l|} 
distances \\
from each \\
source to \\
each site $[\mathrm{km}]$
\end{tabular} & $\begin{array}{l}\text { technology } \\
\text { and efficiency } \\
\text { of asphalt } \\
\text { laying [thour] }\end{array}$ & $\mathrm{n}$ & 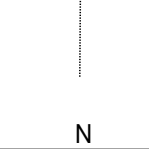 & $\mathrm{m}$ & & \\
\hline
\end{tabular}

Figure 2 Input parameters, illustration of model, and illustration of result exporting

\subsection{Case study}

For the case study, we made a generic model of a typical process chain in asphalt paving, which consists of production, transport, and paving of a hot asphalt mixture. The input parameters for the model are:

1) Production: The number of asphalt plants is $n=10$; the nominal capacity of each plant is $90-150$ tons/hour

2) Transportation: the number of trucks is $N=7$; the capacity of each truck is 5 tons

3) Sites: the number of sites is $m=7$; the needed quantity of asphalt is 2000-5500 tons; the efficiency of the asphalt-laying machines on site is $30-50$ tons/hour

All locations and distances were generated in Excel format as a matrix of distances between the asphalt plants and construction sites, assuming the transportation trucks have an average speed of $50 \mathrm{~km} / \mathrm{h}$.
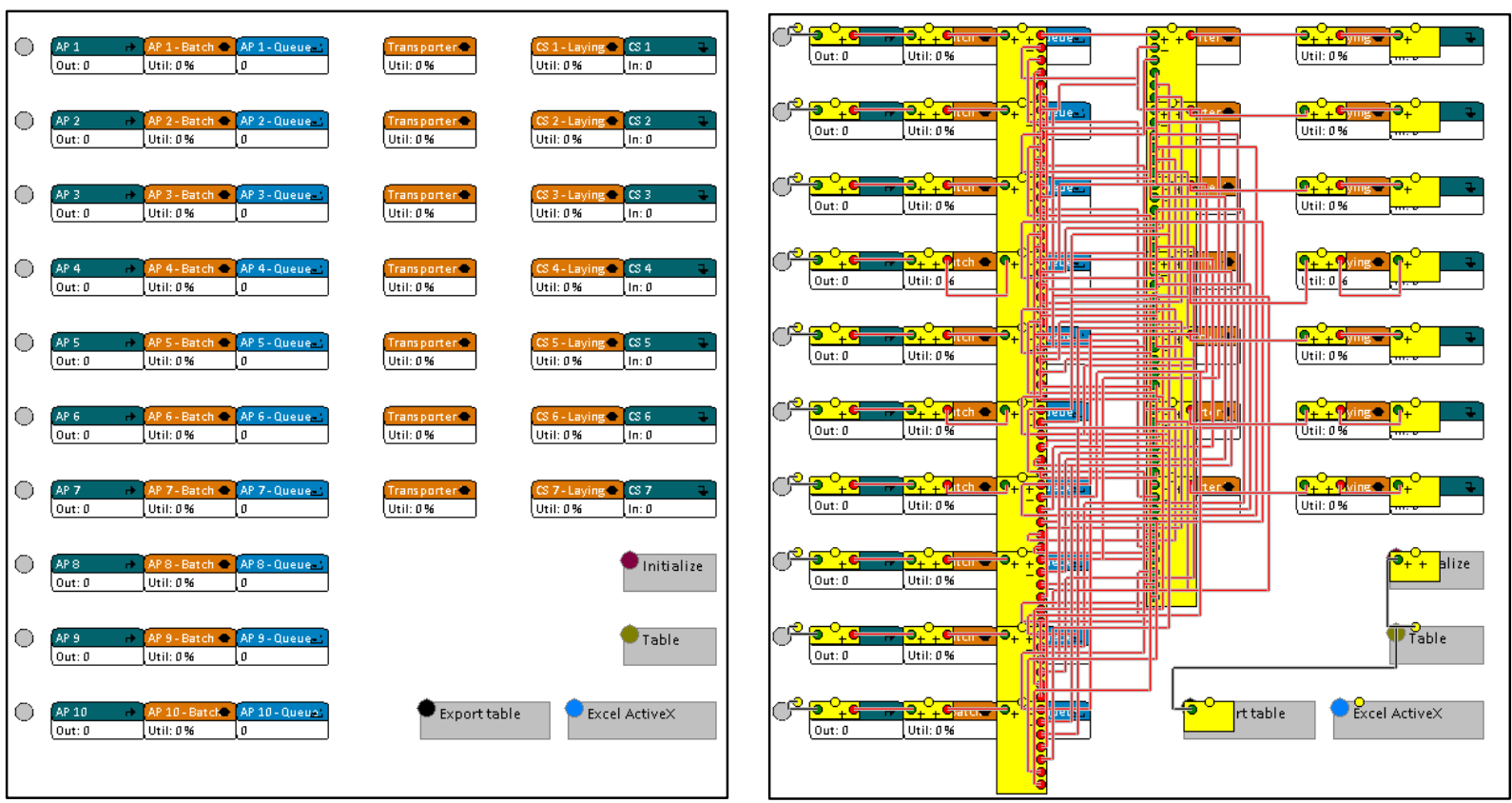

Figure 3 Structured model (left) and the same model with highlighted channels and connections (right) 
Figure 3 shows an illustration of the structured model; the left side is the state before the simulation, and the right side shows how the channels are connected between the sub-processes in the model. In the following subchapters we will explain all these segments.

\subsubsection{Production model}

The asphalt plants are sources of HMA and are characterized by the parameters "tons per hour" and "batch size." A plant is built from three atoms: a "source," a "server," and a "queue." The "source" produces the asphalt, depending on the capacity of the plant, which is extracted from the Excel table. Every product from the plant gets the label "asphalt" (Figure 4) to ensure that it can later be matched to its "source."

\section{Label ([asphalt], i) := 1}

\section{Figure 4 4D Script for label creation}

The atom "server" is used for loading asphalt into the transport unit. This was done in order to ensure the equivalent quantity asphalt produced and the amount of asphalt transported as one unit which is dependent on the truck's capacity.

\subsubsection{Transportation model}

One transporter is attached to each construction site, and the transporter is represented by the atom "server." The transporter's input strategy was given by description of the order Longest waiting. This means that the product is accepted first, from the atom, whose product entered earliest (if all queues are empty, then open all channels and wait). For each construction site, all values of the "cycletime" for the transporters are given in a generic matrix in Excel; we assume that its values are distributed as a negative exponential distribution (Figure 5).

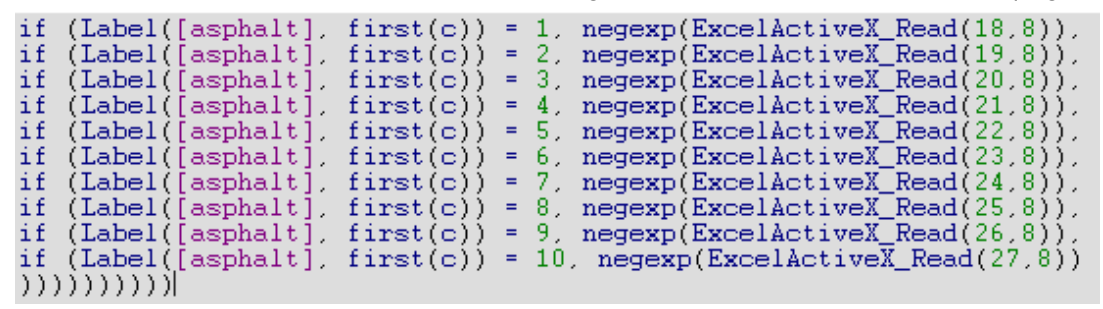

Figure 5 Example of "cycletime" for Transporter1

\subsubsection{Model of the construction sites}

Each construction site is represented by one "server" and one "sink." The process of asphalt laying and rolling is combined in a "server." It is extracting its "cycletime" from the Excel table, which is uniformly distributed among given minimum and maximum values. At the end there is a "sink" atom, which counts the amount of asphalt that has been processed on the construction site (Figure 6).

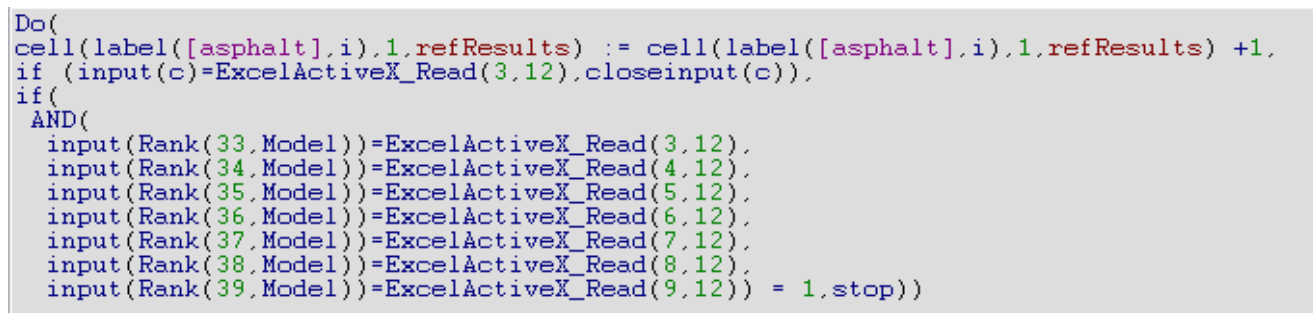

Figure 6 4D Script for the tasks of the "Sink" atom

Additionally, for each construction site, the program records the tons of asphalt received from each plant in a table. Once the needs of all construction sites have been fulfilled, the simulation ends. 


\subsection{Simulation results}

Once the simulation ends, its results are automatically exported from ED to an Excel file. The results are given in a table, which shows how much asphalt [tons] should be ordered from each asphalt plant for each construction site (Figure 7).

\begin{tabular}{|l|l|l|l|l|l|l|l|}
\hline & Site1 & Site2 & Site3 & Site4 & Site5 & Site6 & Site8 \\
\hline AP1 & 220 & 450 & 560 & 270 & 350 & 460 & 330 \\
\hline AP2 & 220 & 300 & 550 & 330 & 330 & 420 & 470 \\
\hline AP3 & 280 & 350 & 480 & 200 & 310 & 460 & 560 \\
\hline AP4 & 210 & 430 & 530 & 280 & 270 & 410 & 500 \\
\hline AP5 & 200 & 340 & 670 & 280 & 250 & 390 & 490 \\
\hline AP6 & 120 & 300 & 560 & 300 & 380 & 430 & 550 \\
\hline AP7 & 220 & 400 & 530 & 230 & 360 & 380 & 510 \\
\hline AP8 & 220 & 330 & 560 & 240 & 330 & 480 & 470 \\
\hline AP9 & 150 & 360 & 520 & 400 & 290 & 460 & 450 \\
\hline AP10 & 160 & 340 & 540 & 270 & 330 & 410 & 570 \\
\hline
\end{tabular}

Figure 7 Simulation results, showing asphalt needed for each site (in tons)

The next output also shows the total simulation time-the real time of the simulation (4 min, $10 \mathrm{~s}$ ) -and the time needed to satisfy every construction site (710 working hours).

\section{CONCLUSIONS}

We analyzed Enterprise Dynamics (ED) simulation software, created for simulating production and logistics in stationary industries, for use in the construction industry. Enterprise Dynamics does not yet have any specially defined atoms for construction projects, but the existing atoms can be modified and new ones can be created by using the 4D Script programming language. Its adaptability and modular design make ED a powerful tool for simulating and analyzing complex processes while monitoring and recording various parameters.

It is possible to connect the model bidirectionally (input and output) with external documents such as MS Excel or Access files, which makes it easy to modify model parameters and analyze simulation results. This compatibility between ED and standard tools are important to it being useful to engineers, who are not yet trained in using special simulations tools.

Our case study shows that ED is suitable for process modeling and scenario simulation in construction. Even though modeling and simulation are mainly used by management, ED offers some benefits for the site manager as well; it allows them to easily identify bottlenecks, logistical clashes, and spatial clashes in the logistical processes, letting them take steps to prevent them. In the future, specific atoms for the construction industry should be developed to improve software performance and give more precise models of construction processes. However, even the current version of ED is an interesting tool for process simulation in the construction industry.

\section{References}

[1] "Leitfaden für Simulationsbenutzer in Produktion und Logistik", 1997: Arbeitsgemeinschaft Simulation in der Gesellschaft für Informatik: Bericht aus den Fachgruppen, Heft 58

[2] Galić, M., Dolaček-Alduk, Z., Uremović, B., 2013: Constructability-Buildability-Izgradivost, e-GFOS, Vol. 4, No. 6, pp. 68-80

[3] Galić, M., Završki, I., Dolaček-Alduk, Z., 2013: Reengineering the construction companies in time of the recession, I. Burcar Dunović, V. Mlinarić, I. Završki, 11. International conference Organization, Technology and Management in Construction, Croatian Association for Construction Management, Dubrovnik, Croatia

[4] Bernold, L. E., AbouRizk, S. M., 2010: Managing performance in construction, John Wiley \& Sons, New Jersey, USA 
[5] Feine, I., Bargstädt, H.-J., 2014: Analyzing interrelation of logistical and technological parameters of construction processes, International scientific conference - Integration, Partnership and Innovations in Construction Sciences and Education, Moscow State University of Civil Engineering, Moscow, Russia

[6] Bangsow, S., 2010: Manufacturing Simulation with Plant Simulation and SimTalk, Springer, Berlin, Germany

[7] Wainer, G.A., Mosterman, P.J. 2011: Discrete-event modeling and simulation: Theory and Applications, CRC Press, Boca Raton, USA

[8] Yahya, M., Saka, M., 2014: Construction site layout planning using multi-objective artificial bee colony algorithm with Levy flights, Automation in Construction, Vol. 38, No. 3, pp. 14-29, doi:10.1016/i.autcon.2013.11.001

[9] Said, H., El-Rayes, K., 2013: Performance of global optimization models for dynamic site layout planning of construction projects, Automation in Construction, Vol. 36, No. 12, pp. 71-78, doi:10.1016/i.autcon.2013.08.008

[10] Zhao, S., Li, Z., 2014: Multi-objective Optimization for Construction Site Layout Planning Problem under Fuzzy Random Environment, Computational Sciences and Optimization (CSO), Seventh International Joint Conference on, IEEE, pp. 641-645, doi:10.1109/CSO.2014.148

[11] Nassar, K., Thabet, W., Beliveau, Y., 2003: Simulation of asphalt paving operations under lane closure conditions, Automation in Construction, Vol. 12, No. 5, pp. 527-541, doi:10.1016/S0926-5805(03)00005-0

[12] Marasini, R., Dawood, N., 2002: Simulation modeling and optimization of stockyard layouts for precast concrete products, Simulation Conference, 2002. Proceedings of the Winter, Vol. 2, IEEE, pp. 1731-1736, doi: 10.1109/WSC.2002.1166458

[13] I.S. Solutions, Enterprise Dynamics Tutorial, Utrecht, the Netherlands

[14] Latki, B., Pitsch, H., Greinert, C., Meyr, C., 2010: Prozess-Simulation als Methodenwerkzeug für den Funktionsnachweis komplexer Infra-und Suprastrukturplanungen am Beispiel eines Terminals für den intermodalen Ladungsverkehr, Integrationsaspekte der Simulation: Technik, Organisation und Personal: Karlsruhe, 7. und 8. Oktober 2010, Vol. 131, pp. 245

[15] Neumann, L., Szewczyk, M., RABE, M., 2008: Abbildung von Yard-Management-Prozessen in Simulationsmodellen, Advances in Simulation for Production and Logistics Application, pp. 289-298

[16] Schuh, G., Kampker, A., Potente, T., Stollwerk, A., Müller, C., 2010: Wertstromorientierte Konfiguration der Produktionssteuerung mit Enterprise Dynamics, Integrationsaspekte der Simulation: Technik, Organisation und Personal: Karlsruhe, 7. und 8. Oktober 2010, Vol. 131. pp. 413

[17] Weber, J., 2008: Simulation von Logistikprozessen auf Baustellen auf Basis von 3D-CAD Daten, Doctoral thesis, Fakultät Maschinenbau, University of Dortmund

[18] Günthner, W. A., Venn, E., Ulbrich, A. S., ten Hompel, M., 2007: Simulationsgestützte Grobplanung von Kommissioniersystemen, Institut Materialfluss und Logistik, T. München 